\title{
The End of Cold War and Thereafter:
}

\author{
A Perspective of Evolutionary World Politics
}

Jong Young Ye

(Korea University)

\section{$\langle$ Content $>$}

I. Introduction

П. Global Leadership and the Long Cycles of World Politics
III. A Comparison of Post-Cold War Projections of World Politics

IV. The Grounds for Hope

V. Conclusion

- Key Words: Long cycle theory, Evolutionary world politics, Global leadership, Global War, Coalition-building.

\section{【ABSTRACT】}

This paper attempts to analyze the ongoing events of world politics since the end of the Cold War and presents a projection for the long-term future unfoldings from the perspective of long cycle theory. In doing so, it doesn't treat current events as a series of particular episodes; rather, it draws attention to global systemic process as long cycle theory is deeply rooted in. First, this paper offers a short introduction of global leadership and its evolutionary perspective. This leads to an analysis of the current phase of world politics in which contending interpretations of leading theorists are compared with an evolutionary interpretation. An evolutionary perspective of world politics suggests that the nature of global leadership will be affected by and transformed through the cumulative and collective force of economic, social, and cultural co-evolution. It also suggests that in the long run global institutions that are better shaped for managing global problems will continue to emerge.

* This work was supported by the Brain Korea 21 Project in 2004. 


\section{Introduction}

For nearly two centuries prior to the two World Wars, America had been reluctant to come to the front of world politics as a great power, using its geographic isolation to avoid entanglement in Europe's Westphalian system of sovereign states. 1) It is true that, even as Great Britain entered into its Victorian Sunset while the United States was enjoying robust development, America continued to shrug off the mantle of global leadership. With the close of the Second World War, however, Washington did move decisively to orchestrate the post-war revival of democratic, capitalist societies in the face of global communist expansion. The Unites States managed to develope close relationships with major powers in Europe and Japan that was seen as an integral element of its containment strategy. The relationship of the United States with these major powers had become mutually dependent politically and economically, but nevertheless, retained a certain distance from one another.

With resurging economy during the past decade of 1990 s, the United States seemed to have largely managed to defy the imperial over-reach or "hegemonic decline" thesis2); it emerged as and seemed to remain the world's foremost engine of economic growth as well as its only remaining military superpower at the end of the Cold War. Upon entering the twenty-first century, however, the U.S. needed to redefine its relationships with other major powers: the abrupt end of the Cold War brought with it some languidness in efforts to set up a new agenda. The terrorist attack of September 11 must have been a wakeup call on the part of the U.S. in that regards. In the beginning, the terrorist attack seemed only to facilitate the necessity of that process. It gave the U.S. a fresh opportunity to reinvigorate its relationship with other major powers who found common interests in a war against terrorism. However, a strong support for the U.S. in Europe and around the world didn't last long mainly because of the way the U.S. handled Iraq. ${ }^{3)}$ The future condition of world politics and the relationships among major powers now seems to greatly depend upon how the war against terrorism and in Iraq will be concluded.

This paper attempts to interpret the current situation of world affairs and project the future from the perspective of long cycle theory: it attempts to fit them into a long-term

1) Although it might have belittled the U.S. efforts during the World War II, Andre Malraux once told Richard Nixon in the Early 1970s that "the United States is the first nation in history to become a world power without trying to do so," Cited in John H. Makin, "American Economic and Military Leadership in the Postwar Period," in John H. Makin and Donald C. Hellmann(eds), Sharing World Leadership?: A New Era for America and Japan (Washington, DC: American Enterprise Institute for Public Policy Research, 1989), p.39.

2) See Paul Kennedy, The Rise and Fall of the Great Powers: Economic Change and Military Conflict from 1500 to 2000 (New York: Random House, 1987).

3) See Ronald D. Asmus, "Rebuilding the Atlantic Alliance," Foreign Affairs, 82-5(2003), pp.20-31. 
world political process, rather than treating current events as a series of particular episodes. The task of projecting possible future scenarios also needs the elaboration of a critical historical perspective. The aftermath of the September 11 attack and the relationships among major world powers as a result of it deserve special attention as a global systemic process. To this end, we need a coherent theoretical framework that deals with global leadership, coalition building and maintenance, and the future prospect of the relationship from the standpoint of global systemic process.

\section{Global Leadership and the Long Cycles of World Politics}

This paper is not an introductory attempt to explain long cycle theory. However, it is necessary to mention some pertinent subjects of the theory for further discussion. Long cycle theory, based on the evolutionary approach to world politics, presents a comprehensive, macro-historical, multi-dimensional model of global development.4) Although the theory itself is of comparatively recent vintage compared to now popular theories of international relations, evolutionary approaches to the social sciences were already highly developed by the concluding decades of the nineteenth century. Nevertheless, the notion that periodic regularities in the international political system can be explicated through evolutionary analogies has hardly enjoyed support within the mainstream discipline of international relations.5) Since the first work on the theory, numerous works have been accumulated, its major hypotheses tested, so that the theory itself has become articulated, although evolutionary world politics is still a school of thought in progress.

The basic premise underlying all the studies on the long cycle theory is that the global

4) There is no single unified version of evolutionary theory in the field of international politics that explains all the aspects of world phenomena. Long cycle theory is one example of many possible evolutionary approaches that attempts to explain long-term structural changes of world political system with a focus on the nature of global leadership utilizing phased mechanisms of evolutionary processes. On this point, see George Modelski, "Evolutionary World Politics: Problems of Scope and Method," in William R. Thompson(ed.), Evolutionary Interpretations of World Politics (London: Routledge, 2001), pp. 16-29.

5) In fact, when Modelski began the work on the long cycle theory, he himself did not immediately construe patterns of temporal succession in the concentration of sea power and the related rise and fall of dominant or "leading" nation-states in evolutionary terms, per se. He initially interpreted them as some type of systemic phenomena having positive and negative feedback loops, and only subsequently recognized their correspondence to evolutionary processes. See George Modelski, "The Long Cycle of Global Politics and the Nation-state," Comparative Studies in Society and History, 20-2(1978), pp.214-35. 
political system displays regularities that are amenable to analysis and possible prediction. That being so, the world system itself is neither disorderly nor anarchic: it might be "chaotic" in the sense of chaos theory which really means "hidden order". There are variations on world system theory, but for all world system theorists, the focus of analysis is not the nation-state arrayed against its peers at a given point in historical time, but the system as a whole evolving across historical time.6)

The development of the long cycle model began with research into the temporal periodicity of global war since the start of the fifteenth century. The central findings were that global wars have occurred during the modern era on a regular basis and that each has been followed by a prolonged period in which one nation on the "winning side" has emerged as the leading world power. When we survey global politics over the past five or six centuries, Modelski wrote, "the dominant fact would seem to be that the active focus for global organization...has always been a world power and that the identity, values, and resources of that power have shaped long stretches of modern world experience." 7 ) This concept of world power would be articulated in later works as global leadership, taking it to denote the "capacity and opportunity to advance the solution of global problems".8) Responsiveness to global problems requires willingness on the part of the leader to address cross-border issues, e.g., threats to global security, global environmental pollution. The leader must have great capacity to mobilize global public opinion and, hence, galvanize

6) William Thompson (1983) has argued, all world systems theories share three assumptions: (I) that a world system exists; (2) that world system structure and its critical processes explain behavior within this system; and (3) that approaches to studying that system must be cross-disciplinary. See William Thompson, "Introduction: World System Analysis With and Without Hyphen," in William R. Thompson(eds.), Contending Approaches to World System Analysis (Beverly Hills, CA: Sage Publications, 1983), p.7-24. He also observed that "what each perspective on world system history shares is a commitment to the idea that contemporary structures and processes are embedded in a long-term, historically contingent context". William Thompson, "Comparing Approaches to World System Analysis," in Robert A. Denemark, Jonathan Friedman, Barry K. Gills and George Modelski(eds), World System History: The Social Science of Long-Term Change (London: Routledge, 2000), p.287. It is critical to note here that while the study of long cycles in global leadership encompasses a period of few hundred years, the "master processes" of the world system extend back several thousand years. See George Modelski, "World System Evolution," in Denemark, Friedman, Gills and Modelski(2000), pp.24-53.

7) Modelski(1978), p.216.

8) George Modelski, "Global Leadership: End Game Scenarios," in David P. Rapkin(eds), World Leadership and Hegemony (Boulder, CO: Lynne Rienner Publishers. 1990a), p.241. Originally, Modelski defined "world power" as "functional network control," the prime exampie being control of trade routes/sea lanes. Modelski(1978), p.229. Each of the nations that had risen to global power status possessed the requisite means to achieve functional network control in the form of superior military and merchant fleets, and each avoided large-scale territorial acquisitions open to assault by contending land powers. 
common efforts toward the resolution of societal issues. Such cooperative efforts hinge, in part, on the perception that the leader's ideology is authentic or legitimate and that its proposed solutions to international issues hold forth the promise of mutual absolute gain. The concept of global leadership is of great importance in the long cycle theory in that "[F]rom a long-cycle perspective, there are recurring events, processes, and phases of world system history that cannot be comprehended in horizontal terms, i.e., without reference to a state extraordinary in both the ends it seeks and the means it employs."9) While both neorealism and institutionalism recognize "hegemons," neither construes their dominance in terms of leadership qualifications or functions.

A long cycle is equivalent to the "term" that a particular nation holds the "office" of global leadership. Since the early fifteenth century, there have been four completed long cycles outlined in Modelski's work.10) Presently, the world is in the leadership cycle of the United States, beginning in 1945 and is, therefore, projected to end sometime around the middle of the twenty-first century. As the presence of two successive terms for Great Britain connotes, however, it is entirely possible that the "incumbent" United States will be "re-elected" (or, more properly, "re-selected" through evolutionary processes) for a second term as the world's leader.

Every long cycle consists of four distinct phases, each of which extends over a period of twenty-five to thirty years, equivalent to a human generation. The sequence of evolutionary analogs is that of (1) selection, (2) amplification, (3) variation, and (4) cooperation. The sequence corresponds to the long cycle's phases of (1) macrodecision, (2) leadership execution, (3) agenda-setting, and (4) coalitioning. 11)

The execution phase corresponds to the evolutionary process of amplification/reinforcement. It typically represents the apogee of the global leader's power. The execution phase of the American long cycle, for example, began at the end of World War II and extended until the early 1970s . During this period, the leading nation typically addresses the central problems of the prior cycle and takes the initiative in constructing an improved institutional infrastructure to deal with them. Since collective security and economic protection were the dominant unresolved problems of the inter-war period, after World War II, the United States "amplified and reinforced" the old global system with new and more effective

9) David. P. Rapkin, "World Leadership." in George Modelski (eds.) Exploring Long Cycles (Boulder, CO: Lynne Rienner Publishers, 1987), p.129.

10) For the matrix of modern evolutionary world politics, refer to Modelski(2000), pp. 50-51.

11) "Agenda-setting" brings policy innovation unto the global agenda through variation. "Coalitioning" manifests the importance of cooperative action in global affairs. "Macrodecision" is the selection process of that system; and "Execution" is an opportunity for amplification, diffusion of innovations, and the building of memory. See George Modelski, "Evolutionary Paradigm for Global Politics," International Studies Quarterly 40-3(1996a), p.336. 
mechanisms. Thus, as the global leader of the post-war world, the United States took the initiative in the creation of the United Nations as an instrument for global security. It was also the main force behind the establishment of the International Monetary Fund (IMF), the World Bank (IBRD), and the General Agreement on Tariffs and Trade (GATT), in order to ensure the growth of global trade. During its amplification/execution phase, the United States acted as a guardian of the world's productive infrastructure, using its premier naval might to protect trade and telecommunications routes/networks.

In the agenda-setting phase of the long cycle, the old problems addressed by the global leader through the execution phase give way to a new set of issues, some of which are generated by solutions to the old problems, others of which simply rise in importance. This is a process of variation in which the basic assumptions of the improved old system are challenged along with the leader's support for them. As a consequence, "delegitimation" occurs during this stage. The United States entered the agenda-setting phase of its leadership cycle in the early 1970s, a phase that would come to its "natural" end in around the year 2000 .

The "coalitioning" or "coalition-building" phase of the long cycle emerges as nations cohere around different solutions or approaches to the new issues established during the agenda-setting phase. The evolutionary process analog of this stage is "cooperation," but the global political consequences include a redistribution or "deconcentration" of power away from the incumbent global leader. Unless we assume that the end of the Cold War may have somehow truncated the normal time span, the United States would now be on the cusp of entering into this "coalitioning" phase, which, or so the theory goes, would be likely to extend until around the year 2026. The last coalition-building phase to occur was between the years 1873 and 1914; this was, of course, a period in which the major European powers entered into military alliances that challenged Great Britain's world leadership.

The second British long cycle came to an end with World War II, and can be seen as the end of the "macrodecision" phase, which corresponds to the evolutionary process of "selection." Given Modelski's interests in the periodicity of global war, he noted, in an early paper, that "each cycle known so far comprises and may be said to originate in a period of weak organization (sometimes verging on near anarchy) that ultimately transforms or dissolves into global war."12) In his earliest conception of the long cycle, Modelski asserted that all long cycles have been marked by a global war.

More recently, however, as the theory has evolved into a more comprehensive theory of world system evolution, it has begun to entertain the possibility that a macrodecision

12) Modelski(1978), p.217. 
in the current (and future) long cycles need not take place through global war or through any form of armed conflict. ${ }^{13)}$ Adopting an optimistic perspective, Modelski has argued that the very nature of global leadership might change as the cumulative, co-evolutionary process of democratization is strengthened under U.S. leadership. ${ }^{14)}$ Selection would still occur through a macro-decision process which, according to the theory, would be scheduled to take place around 2026; but this might well take place through the emergence of democratic institutional and communal forms.

The possibility of a long cycle leadership transition without global war would have enormous consequences for the criteria operative in future leadership selection. First, if the transition does not involve war, the salience of the great arsenals will be significantly diminished. The sort of power that will be relevant will be different from what it is now. Second, the office of leadership, while becoming better institutionalized, will be spread thin by specialization on global as opposed to regional outcomes, devolving functions to special international regimes for routine problems, allowing greater concentration on priority global tasks. ${ }^{15)}$ Because the long cycle nests within much broader evolutionary processes taking place within the world system, its content undergoes significant change necessarily through long run accumulations.

\section{A Comparison of Post-Cold War Projections of World Politics}

\section{Contending Interpretations}

In response to the end of the Cold War, Kenneth Waltz has argued that despite its failure to predict the collapse of the world's bipolar division of power, the basic premises of the neorealist theory remained intact. Nations continued to pursue their own calculated self-interests within an anarchic environment, Waltz asserted. Indeed, he maintained that during the 1990s, "the winner of the Cold War and the sole remaining great power has behaved as unchecked powers have unusually done. In the absence of counterweights, a country's internal impulses prevail, whether fueled by liberal or other urges."16) In other

13) Modelski(1990a), p.251.

14) Thus, in 1990, he speculated that "the role of leadership will not itself remain unchanged---it is likely to evolve into forms of cooperative and consensual leadership (or co-leadership) of which a variety of practices...have already begun to serve as working models" Modelski(1990a), p.253. See also G. John Ikenberry, After Victory (NJ: Princeton University Press, 2000).

15) See Ibid, p.253.

16) Kenneth N. Waltz, "Structural Realism after the Cold War," International Security, 25-1(2000). pp.5-41. 
words, America has used the "clear field" opportunity furnished by the demise of the USSR to promote and/or reinforce a world order that favors its national interests without regard to the stability or the equity of that order.

Waltz argued that the United States would not be able to maintain its post-Cold War supremacy, that "the American aspiration to freeze historical development by working to keep the world unipolar is doomed"17) His reasoning here was a variant on the hegemonic decline thesis. Waltz wrote that "in the not very long run, the task will exceed America's economic, military, demographic, and political resources; and the very effort to maintain a hegemonic position is the surest way to undermine it."18) What will take place, instead, is that other major powers, e.g., Japan, the European Union, China, and Russia, will emerge to form coalitions aimed at checking U.S. aggrandizement. In Europe, a German-led EU will gravitate toward Russia and its former Warsaw Pact allies; in Asia, Japan is likely to move toward a coalition with Russia as a counterweight to both the United States and to China. Eventually, the United States will withdraw from NATO and leave Asia to provide its own security arrangement against prospective Chinese aggression.

In Waltz's vision of the future, then, the basic mechanisms of the "coalition-building" phase of the long cycle model yield an adversarial environment in which other major nations form alliances against the United States. In the context of America's strained capabilities, these oppositional coalitions will cause the United States to withdraw from its leadership role, rescinding its provision of collective public goods and thereby prompting other states to develop the ability to defend themselves from external security threats. Under these circumstances, the possibility of an armed conflict erupting between the major nations of a multi-polar global order is magnified.

Waltz is not the only scholar to present pessimistic projections for the post-Cold War world. In Paul Kennedy's estimation, the rapid pace of technological change will generate severe externalities, including environmental problems and widening socioeconomic disparities that no nation or coalition of powers will be able to successfully address. The result is a highly uncertain future headed toward chaos. ${ }^{19)}$ The multi-polar structure of Samuel Huntington's post-Cold War yields seven or eight different "civilizations," with liberal democracy confined to its original nucleus in Western Europe and North America, and Japan. Japan, for its part, would gravitate toward a pan-Asian cultural identity in concert with China and defined against the "West".20)

17) Ibid, p.36.

18) Ibid, pp.36-37.

19) Paul Kennedy, Preparing for the Twenty-First Century (New York: Vintage Books, 1993).

20) Samuel Huntington, The Clash of Civilizations and the Remaking of World Order (New York: Simon \& Schuster, 1996). 
Cultural differences are the basis of Samuel Huntington's "multi-polar" projection for the course of world order. Huntington' model leads to the prediction that seven or eight "civilizations" will arise such that the United States and its closest cousins, e.g., Canada and the United Kingdom, comprise one such center of power, while Japan would gravitate toward an Asian coalition encompassing China and, possibly, India. From the perspective of evolutionary world politics, rather than being divided into cultural spheres, the ongoing processes of globalization, democratic community formation, and the growth of informed world opinion exert centrifugal forces on societies and cultures around the world. Rather than growing apart, different societies and cultures are both contributing to global culture that facilitates globalization but permit traditional differences organized around common core values, most notably political and economic freedom as well as social and cultural heterogeneity.

Immanuel Wallerstein's approach to global politics shares evolutionary world politics approach's cardinal assumption that basic changes in world order are inevitable, operating independently of "rational choice" policy consideration. ${ }^{21)}$ In his model, the United States and Japan comprise a unity of hegemonic power that rests upon the common exploitation of less developed political economies on the periphery or semi-periphery of the world system. In Wallerstein's view, multiple futures are possible at the present "bifurcation" point in global development. One such possibility is the formation of a U.S./Japan/China hegemonic nucleus in adversarial opposition to an EU/Russia power center. A second possibility, from Wallerstein's perspective, is the devolution of the current hegemonic order into chaos.

Contrary to Wallerstein's interpretation of recent history and his projections for the future course of global development, however, the tendency has been toward closer contacts between the United States and Japan, on the one hand, and the European Union, on the other, as epitomized, for example, by the role of the G-8 nations in managing and responding to global economic problems. Rather than hegemonic exploitation, the overall tendency has been toward increased trade and financial flows among the developed nations upon mutually acceptable and beneficial terms.

Lastly, in a widely publicized treatise, Francis Fukuyama asserted that the conclusion of Cold War amounted to the "end of history" in the sense that liberal democracy had triumphed and no further basic evolution in the global order will be forthcoming. ${ }^{22)}$ As

21) Immanuel Wallerstein,"Peace, Stability, and Legitimacy: 1990-2025/2050." in Geir Lundestad(eds.), The Fall of Great Powers: Peace, Stability, and Legitimacy (New York: Oxford University Press, 1995.), pp.331-349; "The Global Picture, 1945-90." in Terence K. Hopkins and Immanuel Wallerstein(eds.), The Age of Transition: Trajectory of the World System, 1945-2025. (London: Zed Books, 1996a), pp.209-25; "The Global Possibilities, 1990-2025." in Ibid(1996b), pp.226-243. 
the evolutionary approach has observed prominently, democratization does not end with the world's leading powers operating on democratic principles inside their borders. Indeed, the United States has been operating as an important agent of democratization beyond its own polity, although there have been debatable trials and errors. From the perspective of evolutionary world politics, the U.S. will play leading role in the spread of democratic values as its sources for global innovation and leadership continues to hold up.

\section{An Evolutionary Interpretation}

Although an evolutionary analysis does not predict the timing of events, we have to ask whether the end of the Cold War was the event of a major transition in world system, such as change in the office of global leadership. In substance, it was part of the phase movement, in global politics, of delegitimizing the post-1945 order in Eastern Europe. Moreover, the broader significance of the Cold War was that of ideological competition between democracy, and the Soviet model of social organization. Hence it was part of the selection phase of the process of democratization. ${ }^{23}$ ) The moral, economic, and political bankruptcy of the communist system in the Soviet Union and Eastern Europe signified the non-selection of the model offered by the USSR as a possible nucleus of the global community. ${ }^{24)}$ Note also that this means that democratization is not simply cumulative--that is, it has been shown to go down as well as up--- but in fact a non-linear evolutionary process recently experiencing a strong surge. In a manner self-similar to long cycles (but doubles its length, with a period of maybe 240 years), the evolutionary process of democratization passes through phases of variation, cooperation, selection--- with variation starting about 1850, cooperation in 1914 and selection in 1973. On this account, the selection phase of that process is not over yet. ${ }^{25}$ )

It is interesting to note that the time September 11 attack occurred fell into the beginning period of the "coalitioning" phase on the long cycle timetable. The long cycle model projected that the United States would enter into the "coalitioning" phase of its global leadership term around the year 2000, and that the following quarter century or so would be characterized by a significant decline in its power. Modelski and Thompson re-affirmed the historical basis of this forecast by noting that "[I]n past experience, the phase of coalition building has been marked by a deconcentration of economic and political power--- that is, by decline, or the loss of the margin of superiority enjoyed by

22) Francis Fukuyama, The End of History and the Last Man (New York: The Free Pres,1992).

23) See Modelski(2000), pp.43-53.

24) See Modelski(1996b).

25) Ibid. 
the sitting world power, and the rise of new centers of economic and political influence. "26) In prior long cycles, leading world powers have confronted severe challenges during such "coalitioning" phases, as other nations formed alliances against them to advance their preferred solutions to issues raised during the preceding agenda-setting or variation phase of the cycle. This, in turn, created the pre-conditions for a macrodecision, and since the Portuguese cycle, the selection of a new leader has occurred through global war.

Considered apart from the co-evolutionary processes and the evolutionary world politics approach that have been since integrated into, the long cycle model implies a scenario for the first half of the twenty-first century that bears some resemblance to the pessimistic views of "hegemonic decline" put forth, inter alia, by Paul Kennedy, Samuel Huntington, and Kenneth Waltz. Currently, worsening situation in Iraq on the part of the U.S. seemingly supports such a view: U.S. ties with major powers seems unstable, if not deteriorated, and its formidable power at the beginning of the Iraqi War seems quite shrunken. Seen from the evolutionary perspective, however, mounting conflict is not an inevitable characteristic of the long cycle's "deconcentration" phase. The evolutionary interpretation suggests, instead, that the nature of global leadership itself will be transformed through the cumulative and collective force of economic, social, and cultural co-evolution. In essence, it argues that a consensual form of global leadership will replace the historical pattern of a single nation-state seeking to execute its preferred responses to world problems. There is no reason to shut the door on the hope that "in the long run global institutions (both intergovernmental and nongovernmental) that are better capable of managing global problems will continue to emerge."27) The following section discusses the basis for such optimism on this account in more detail.

\section{The Grounds for Hope}

As noted above, while Modelski and Thompson do not believe that the leadership of the United States in the "coalition-building" phase will remain unchallenged, they have nonetheless asserted that the pattern of other major nations forming alliances against the global leader may not hold true in the current long cycle. That being the case, it may be possible (indeed, likely) for the world system to move into the next long cycle without

26) George Modelski and William R. Thompson,"The Long and Short of Global Politics in the Twenty-First Century: An Evolutionary Approach," International Studies Review, 1-1(1999), pp.109-140.

27) Modelski and Thompson(1999), p.119. 
a global war. The over-arching reason for this relative optimism lies in economic, social, and cultural co-evolutionary processes that have accelerated and become increasingly powerful as determinants of global political order since the mid-nineteenth century.

\section{Economic Co-Evolution: the Knowledge Economy}

The study of the evolution of global systems has been enriched by the observation of co-evolutionary economic, social, and cultural cycles, among them Kondratieff Waves or $\mathrm{K}$-waves, cyclical patterns of leading economic sectors, which were distinct from but intertwined with geo-political long cycles. ${ }^{28)}$ In themselves, the K-Waves are non-linear, recurrent evolutionary process, showing S-shaped growth spurts. In the evolutionary world politics approach, K-waves are connected to the world political development, which is a cumulative process with a discernible direction. Hence, as the locus of the world's economy shifted from Western Europe to the United States, the latter became the epicenter of economic innovation during the "start-up" phases of the past three K-waves. In the near term, technical innovations that arose in the United States are now fueling the "high growth" stage of the current K-wave. On this subject, Modelski and Thompson have remarked:

Since the 1970 s, leadership in the global economy has been shifting to a new set of leading industrial sectors. This shift, having been underway in a "take-off" phase for some two or three decades (1973-2000), will around the year 2000, enter upon the phase of "high growth" (2000-2026) that will place at the center of the world economy a set of industries centered on the computer but including media and communications, which are collectively referred to as the information industries.29)

These information industries, however, are the latest manifestation of what Modelski and Thompson refer to as the Knowledge Economy. It was in the 1850 s, that the chemical and the electrical sectors of the United States became the first industries to develop on the basis of scientific research. These, in turn, fueled the development of consumer electronics sectors- telephones, radio, and television- capable of transmitting information/knowledge across long distances. As this occurred, the first infrastructural

28) See George Modelski, "Long Cycles and the Strategy of U.S. International Economic Policy," in William P. Avery and David P. Rapkin(eds.) America in a Changing World Political Economy (New York: Longman Inc., 1982), pp.97-116; Modelski(1996a); Modelski and Thompson(1996). 29) Modelski and Thompson(1999). 
elements for an integrated world economy came into being. Thus, it is by no means a coincidence that a movement toward freer cross-border trade accompanied the shift to a Knowledge Economy in the 1850 s. The Knowledge Economy has taken a quantum leap forward with the emergence of digital information technologies in the $1970 \mathrm{~s}$, leading to the advent of the World Wide Web. The information industries are the keystone of the Knowledge Economy and the foundation of recent economic globalization.

On the one hand, the $\mathrm{K}$-wave pattern now in place strongly indicates that the world will enjoy a prolonged period of relative prosperity as K-19 information technologies are fully commercialized and disseminated across the globe. Such "high growth" K-wave stages have not prevented the occurrence of war; to the contrary, there appears to be a positive correlation between the high growth phase of $\mathrm{K}$-waves and the frequency of war. This time, however, the "knowledge" basis of the leading sectors in K-wave militates against warfare both directly and indirectly. They do so directly by creating an extraordinarily efficient (low-cost) global network through which information can be shared. They do so indirectly by facilitating international trade and by reinforcing economic interdependences.

\section{Social Co-Evolution: Democratization}

The second co-evolutionary process that argues for a departure from the conflictual character of prior coalitioning phases in the long cycle is democratization. ${ }^{30)}$ Like the Knowledge Economy, democratization entered into a take-off stage around the middle of the nineteenth-century. At that time, the seminal steps toward democratization had already been taken by the Dutch and the British, and the epicenter for the spread of democratic government shifted to the world's active zone in the Western Hemisphere, the United States becoming the inheritor of the European democratic tradition. In 1850, less than 4 percent of the world's population lived in democracies; by the year 2000 , however, more than half of the world's population resided in nations with open, representative governments. ${ }^{31)}$ Democracy being taken as a "technology of cooperation." and based upon diffusion rates for technologies in general, it is projected that an overwhelming preponderance of the world's populace will enjoy democratic governance by the end of the twenty-first century.32) Democracies tend to be cooperative societies that resolve

30) See Fukuyama(1992); Modelski and Thompson(1999), pp.128-29.

31) George Modelski and Gardner Perry, III, "Democratization in Long Perspective," Technological Forecasting and social Change 39(1991), pp.22-34; Modelski and Thompson(1999), p.128.

32) Modelski and Thompson notes that "[J]udging by the trends just described and assuming their continuance, it can be prognosticated that a level of 90 percent coverage of the world population 
domestic issues through electoral means and address foreign policy disputes through diplomatic negotiations. Therefore, as democracy becomes increasingly prevalent, the probability of a global war has undergone a commensurate decline.

Modelski and Thompson did not truncate their vision of a democratic world at national borders. Instead, they project a future in which nation states still exist but do so within a world-wide democratic community. As they have explained it:

An idea more in line with an evolutionary approach is that of a democratic community emerging in response to the priority global problems of integration. In place of rival power blocs or culture areas, it offers the prospect of a zone of peace based on a consensus for democratic values. In the evolutionary perspective, it is the enhanced cooperation among the democracies (i.e., integration) that is the defining problem of the next few decades of global politics... This is the evolutionary challenge that is the key to understanding twenty-first century global politics. ${ }^{33)}$

In this vision, it is not simply that more nations adopt democratic forms; instead, as democracies reach a critical mass in terms of the proportion of the world's people who live within them, democratic procedures tend to evolve in relation to foreign policy decisions. The reference to the Middle East is particularly germane, for as the extent of the world's democratization level becomes broadened, the Middle East region should experience, if not in the very near future, an acceleration of the democratization process as the time moves on. Under the democratic conditions, an alliance among Arab states against the United States becomes far-fetched: a more likely scenario is that under the influence of democratic nations in the region, non-democratic states and groups will move toward democracy.

\section{Cultural Co-Evolution: the Rise of Informed World Opinion}

With the world "wired" together via information technologies and enjoying an accelerated movement toward universal democracy, a third co-evolutionary process takes

could be attained before the end of the twenty-first century. Long-term thinking about world politics might therefore proceed from the assumption that the world system is likely to be democratic, and hence also likely to be free of major war. On such a basis, a twenty-second-century global democratic community appears entirely feasible, and we need to ask what the implication of that might be for global politics." Modelski and Thompson(1999), p.128

33) Modelski and Thompson(1999), p.139. 
on greater momentum in the rise of informed world opinion. This is essentially a cultural phenomenon, one that will be accompanied by the rise of international non-governmental organizations.

Aided by the maturing of the Knowledge Economy, founded upon the information industries, and by advancing democratization, broad-based world opinion is acquiring solid foundations in world organization, and is likely to be increasingly important for defining global problems... [S]ince the 1970s opinion has begun to shift priorities to problems of integration, that is to strengthening new networks of solidarity and forming nuclei of global community, in contrast to those, fundamentalists and others, resisting the possibility of more inclusive relationships.34) (Modelski \& Thompson 1999, p.128-129)

The scenario here runs directly contrary to that proposed by Samuel Huntington. Rather than seven or eight different civilizations distinguished by cultural, ethnic and/or religious characteristics, the world envisioned here is an evolving global culture, joined together via the Knowledge Economy and committed to a common core of democratic values. With the rise of this cultural phenomena, i.e., world opinion, the major issues of global problems could be defined, values and necessities at the global level could be prioritized by legitimizing some demands and rejecting others. The momentum toward such a trend can be evidenced in two ways besides the widening of democratic integration. First, the rapid growth of the Knowledge Economy provides the technical infrastructure to encourage and create convergence of world public opinion on global problems: the proliferation of the World Wide Web and "the CNN effect" are salient examples. Secondly, the increasing role of international organizations and INGOs helps to build institutional base for the formation of world opinion by providing transnational linkages and networks..

Owing to economic, social, and cultural evolutionary processes delineated above, executed increasingly through institutional modalities, the means through which the long cycle's macrodecision phase has been resolved in the past, i.e., global war, might be replaced by both a new type of decision process and a new type of global leadership. These three inter-penetrating co-evolutionary processes all move in the direction of a social learning and a leadership selection process that is accomplished without war. Modelski and Thompson's explanation of precisely what new macrodecision process will replace warfare as a means for selecting global leaders and when this will occur is somewhat vague.

34) Ibid, pp.128-29. 
Sooner or later, there is likely to arise within a nascent democratic community a stabilized conflict system, mediated by persistent alignments, or possibly even by a party system. The system will be based on divergent approaches to some important global issues, certainly in the inter-government and gradually also in other, nongovernmental and transnational contexts, for the phase of coalition building is likely to continue the experience of rapid growth of organizations and movements aiming to participate in shaping global policies. ${ }^{35}$ )

In a global political system of this sort, however, the role of the global leadership in responding to the world's salient issues would undergo a dramatic transformation. Rather than acting as an extension of its national policies and character, the leader would take part in a consensual decision-making process through global and regional institutions. Institutional dialogue reflecting a broad range of approaches to particular global issues would replace the burden of a single state which has basically monopolized the capacity for managing such problems.

\section{Conclusion}

The evolutionary theory of world politics "predicts" that the first twenty-five to thirty years of the twenty-first century will be a period of power "coalitioning" and the "deconcentration" of power away from the incumbent leader, the United States. Even given the resurgence of U.S. power in the beginning of the 21 st century, we would advance the hypothesis that while the United States will continue to enjoy the strongest and most dynamic economy in the world as well as the greatest capacity for global reach, its leadership credentials will undergo an erosion and new centers of power will arise as potential candidates to the next long cycle. The most severe decline is likely to occur in America's capacity to mobilize collective responses to global issues based upon its long-standing "neoliberal" or "free market" capitalist ideology. It is also possible that an increasingly affluent global economy will become increasingly multi-polar, with regional blocs forming in both Europe and East Asia.36)

35) Ibid, p.132.

36) One could also project that alternative models of economic development to laissez-faire capitalism could be championed. For example, Hellmann has advocated the creation of a dialogue within APEC in which the IMF's single-minded preoccupation with "free market forces" would be juxtaposed with practices seen in the "Asian development. Donald C. Hellmann, "In the Wake of the East Asian Economic Crisis: Toward an Interdependent but Nonconvergent, Global System." 
The terrorist attacks of September 11, 2001 on New York and Washington are widely seen as opening a new phase at least in U.S. foreign policy. From the long cycle perspective, they are not the start of a global war. But having revealed some U.S. vulnerabilities, they have set in motion a deliberate process of coalition-building led by the United States-seeming to mirror the global activities of the Al Qaeda network. Indeed, building a coalition has been one main response of the Bush Administration to the attacks. In so far as terrorism is incompatible with democratization, an anti-terrorist coalition sits well with a design for an emerging democratic community. But it deconcentrates the global power structure, strengthens nation-states, and tends to dampen globalization.

Recent unfoldings since the September 11 attack followed by wars in Afghanistan and Iraq indicates that unilateral U.S. action cannot warrant stable methods to resolve impending global problems. It seems that the crucial task of maintaining global security need to be shared, if not evenly, among several powers, and this will eventually form an essential nucleus for building a winning coalition in the coming macrodecision phase. While the United States will take a leading role in defending the global order, other powers will make significantly greater contributions toward this end that has been true in the past. That is, it could be understood as assembling a possible winning coalition in preparation for the next macrodecision phase. Assembling a winning coalition has been one of the critical tasks of global leadership, and it is important to note that coalitioning is not made only for winning in the macrodecision phase. It will begin to be assembled before and after the macrodecision phase to help solve global problems. The unfoldings since September 11, 2001 only facilitated such a process.

Another point the September 11 attack made clear is that threats to global order during the current coalitioning phase would be less likely to take the form of conflicts between nation-states. In a "shared" model of collective security provision, the challenges to world order may come from non-state actors, e.g., terrorist organizations, and urgent problems that are not the direct product of national policies, e.g., economic recession, global warming, rising trans-border immigration, illegal drug trafficking, etc. Under this hypothesis lies the notion that nation-states are not the only serious actors in the realm of world politics, and variations of policy choices could come from the variety of sources other than nation-states.

The predictions offered by evolutionary theory stand in sharp contrast to those advanced by the prevailing theories of international relations. Indeed, the differences

in Forthcoming Book (2002). In fact, the legitimacy of laissez-faire capitalism could also be questioned. Robert Kuttner, The End of Laissez-Faire: National Purpose and the Global Economy after the Cold War (Philadelphia: The University of Pennsylvania Press, 1991). 
between respective policy prescriptions for the current global problems are amply evident according to the respective theories. In contrast to the "hard" line approach to the current problems, the evolutionary theory of world politics suggests that the United States should pursue a policy of constructive engagement toward opposing parties. After all, evolutionary world politics indicates that the next long cycle will feature progress toward the formation of a global democratic community. Both the rise of INGOs and their interface with global institutions provides some hope for this vision.

The heuristic value of evolutionary world politics theory, its capacity to generate meaningful predictive hypotheses is extremely difficult to assess since it needs long enough time to be proved. In sum, however, it does appear that the United States has lost some of its responsiveness to global problems during the coalition-building phase of its leadership cycle. The September 11 attack not only made such a problem come to the fore, but also triggered coalition-phase of the current cycle. Broader trends, notably globalization, political liberalization, and the rise of informed world opinion must be taken into account in the formulation of projections about the future course of world systems development. 


\section{References}

Asmus, Ronald D. "Rebuilding the Atlantic Alliance," Foreign Affairs 82-5 (2003). Fukuyama, Francis. The End of History and the Last Man, (New York: The Free Press), 1992.

Hellmann, Donald C. "In the Wake of the East Asian Economic Crisis: Toward an Interdependent but Nonconvergent, Global System." in Forthcoming Book, (2002).

Huntington, Samuel. The Clash of Civilizations and the Remaking of World Order (New York: Simon \& Schuster), 1996.

Ikenberry, G. John. After Victory, (Princeton, NJ: Princeton University Press), 2000. Kennedy, Paul. The Rise and Fall of the Great Powers: Economic Change and Military Conflict from 1500 to 2000, (New York: Random House), 1987.

Kennedy, Paul. Preparing for the Twenty-First Century, (New York: Vintage Books), 1993.

Kuttner, Robert. The End of Laissez-Faire: National Purpose and the Global Economy after the Cold War, (Philadelphia: The University of Pennsylvania Press), 1991.

Makin, John H. "American Economic and Military Leadership in the Postwar Period." in John H. Makin and Donald C. Hellmann (eds.) Sharing World Leadership?: A New Era for America and Japan, (Washington, DC: American Enterprise Institute for Public Policy Research), 1989.

Modelski, George. "The Long Cycle of Global Politics and the Nation-state," Comparative Studies in Society and History, 20-2 (1978).

Modelski, George. "Long Cycles and the Strategy of U.S. International Economic Policy." in William P. Avery and David P. Rapkin (eds.), America in a Changing World Political Economy, (New York: Longman Inc), 1982.

Modelski, George. "Global Leadership: End Game Scenarios." in David P. Rapkin (eds.), World Leadership and Hegemony, (Boulder, CO: Lynne Rienner Publishers), 1990a.

Modelski, George. "Is World Politics Evolutionary Learning?" International Organization, 44-1 (1990b).

Modelski, George. "Evolutionary Paradigm for Global Politics," International Studies Quarterly, 40-3 (1996a).

Modelski, George. "Time, Calendars, and IR: Evolution of Global Politics in the 21st Century." Paper presented at the 37 th Annual Convention of the International 
Studies Association, San Diego, (April 16-20. 1996b).

Modelski, George. "World System Evolution," in Robert A. Denemark, Jonathan Friedman, Barry K. Gills and George Modelski (eds.), World System History: The Social Science of Long-Term Change, (London: Routledge), 2000.

Modelski, George, "Evolutionary World Politics: Problems of Scope and Method." in

William R. Thompson(ed.), Evolutionary Interpretations of World Politics, (London: Routledge), 2001.

Modelski, George, and Gardner Perry, III. "Democratization in Long Perspective," Technological Forecasting and social Change, 39 (1991).

Modelski, George, and William R. Thompson. Leading Sectors and World Powers:

The Coevolution of Global Politics and Economics, (Columbia, SC: University of South Carolina Press), 1996.

Modelski, George, and William R. Thompson. "The Long and Short of Global Politics in the Twenty-First Century: An Evolutionary Approach," International Studies Review, 1-1 (1999).

Rapkin, David P. "World Leadership." in George Modelski (eds.), Exploring Long Cycles, (Boulder, C0: Lynne Rienner Publishers), 1987.

Thompson, William R. "Introduction: World System Analysis With and Without Hyphen," in William R. Thompson (eds.), Contending Approaches to World System Analysis, (Beverly Hills, CA: Sage Publications), 1983.

Thompson, William R. "Comparing Approaches to World System Analysis," in Robert A. Denemark, Jonathan Friedman, Barry K. Gills and George Modelski (eds.), World System History: The Social Science of Long-Term Change, (London: Routledge), 2000.

Wallerstein, Immanuel. "Peace, Stability, and Legitimacy: 1990-2025/2050," in Geir Lundestad (eds.), The Fall of Great Powers: Peace, Stability, and Legitimacy, (New York: Oxford University Press), 1995.

Wallerstein, Immanuel. "The Global Picture, 1945-90," in Terence K. Hopkins and Immanuel Wallerstein (eds.), The Age of Transition: Trajectory of the World System, 1945-2025. (London: Zed Books), 1996a.

Wallerstein, Immanuel. "The Global Possibilities, 1990-2025," in Terence K. Hopkins and Immanuel Wallerstein (eds.), The Age of Transition: Trajectory of the World System, 1945-2025. (London: Zed Books), 1996b.

Waltz, Kenneth N."Structural Realism after the Cold War," International Security, 25-1 (2000). 